\title{
STUDY ON THE FINANCIAL PERFORMANCE OF COMPANIES OPERATING IN THE PHARMACEUTICAL INDUSTRY IN ROMANIA
}

\author{
Nicolae Baltes, Ph. D. \\ „Lucian Blaga” University of Sibiu \\ E-mail: baltes_n@yahoo.com \\ Georgiana Daniela Minculete (Piko), Ph. D. Student \\ „Lucian Blaga” University of Sibiu \\ E-mail: georgiana.piko@yahoo.com
}

(Received November 2015; Accepted January 2016)

\begin{abstract}
The study aims at determining the financial performance of companies in the pharmaceutical industry between 2009 and 2014 by means of the indicator of the financial return rate, using multiple linear regressions as research method. By analysing the evolution of the share of companies in the pharmaceutical industry based on the trend of the financial rate of return, we can estimate that the number of entities that resort to supporting the financial activities from loans and liabilities is growing in the period under analysis. This is due mainly to the liquidity crisis faced by entities, as a result of the high recovery duration of debts. Also, using the multiple linear regression we can highlight that, the financial return of pharmaceutical companies is positively influenced by their economic profitability, by the equity multiplier and by inflation, and negatively, by the net profit margin.

Keywords: financial performance, financial return, economic profitability, the method of multiple linear regression, equity multiplier, net profit margin
\end{abstract}

JEL classification: G19, G39

\section{Introduction}

The pharmaceutical industry is one of the industries ranked by Eurostat in "High Technology" which sets a true entrepreneurial example for all the other sectors (Minculete, G.; Baltes, N., 2014, pp. 190-191). This is because the pharmaceutical industry earmarks considerable financial resources for research. According to the communiqué of the European Commission, in 2014, the pharmaceutical industry ranked first in the EU, USA and Japan, as regards investment in R\&D (14.4\%), outpacing industries such as the automotive (4.3\%) and the IT industry (10.4\%) (http://iri.jrc.ec.europa.eu/scoreboard14.html.). As the pharmaceutical industry went global, it strengthened its position among the strongest sectors of the world. Even if, according to Philip Kotler and John Caslione in Chaotics - The Business of Managing and Marketing in The Age of Turbulence, globalization and technology are the main factors that led to striking fragility in the world economy, to shock waves and turbulence both micro-economically and macro-economically, 
for this industry, the turbulence was an opportunity rather than a weakness. The globalization of the economy has gradually led not only to increased competition but also to the development of new technologies (Burghelea, C.; Gheorghiu, A.; Tindechea, C.; Gheorghiu, A., 2014, pp.103-105). In the pharmaceutical industry, new technologies in research and development eventually led to spectacular breakthroughs (Kotler, P.; Caslione, J., 2009, p. 22).

The chart below shows the key market players producing drugs in Romania.

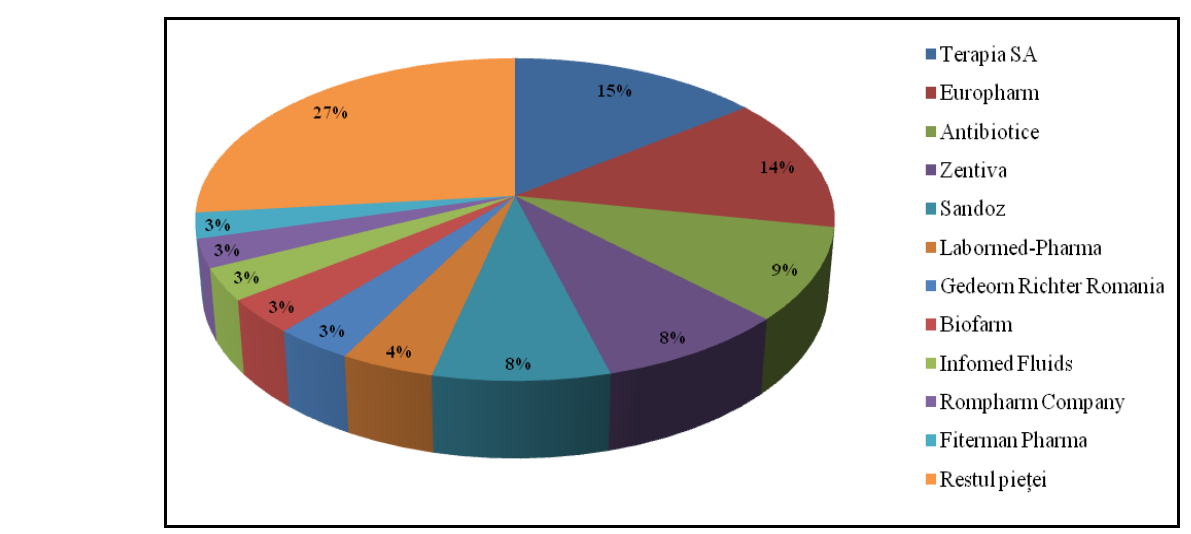

Chart 1: Market share of companies producing drugs for 2013
Source: Data processed by the authors based on the website http://www.firme.info/fabricarea-produselor-farmaceutice-baza-preparatelor-farmaceutice-

COD-CAEN-21/p14.html

The chart indicates that the five major drug companies have a market share of over $50 \%$, which shows a high degree of concentration. The companies listed and traded on the Bucharest Stock Exchange, i.e. Zentiva, Biofarm and Antibiotice, have a market share of over $20 \%$. The added value of the Romanian pharmaceutical sector has increased significantly in recent years. According to data published by the Institute for Economic Forecasting, the sector contributes over 1\% to the GDP, the government cashing from the taxes and fees paid by the drug companies more than $20 \%$ of the market value of existing drugs.

(http://www.lawg.ro/files/assets/userfiles/files/Industria\%20Farmaceutica\%20din\% 20Romania.pdf).

\section{Literature review}

In literature but also in practice, the financial position of the company and the performance of it, are treated from many perspectives. This topic is often discussed and developed at the national level but also at the global level. In a general sense, the financial position illustrates the situation of the assets, liabilities and equity, and 
may be determined based on the balance sheet. Instead, the financial performance is determined based on the profit and loose account, highlighting the level of the excellence registered in the entity analysed, by a great deal of working in a highly competitive environment. Also, empirically shown, profitability is a complex phenomenon with numerous determinants (Mocnik, D., Sirec, K, 2015). Over time, the concept of performance has had an incredible evolution. If at first it was only measured by traditional indicators, then it began to be measured with the help of modern indicators. As we all know, the starting point in any financial analysis, or better said, the source of information for assessing the health of the companies is the annual financial statement, this being illustrated by Higgins Robert in the book Analysis for Financial Management (2012). To better highlight the importance of financial position and performance developments in the international literature, we have captured the main ideas mentioned in bibliographic materials used from the late 90s. So Stanley Eakins highlights the importance of financial analysis in the whole process of determining the financial position and performance and in the paper entitled Finance: Investments, Institutions and Management (1999). Another approach to this subject is found in the book entitled Finance (2000), written by Zvi Bodie and Merton Robert specific rates of the performance and financial position illustrating existing health in the entity, and also illustrate the company's position over its competitors. This idea is strengthened over years of Cotter Derry in the book Advanced Financial Reporting - complicating Guide to IFRS (2012), stating that as health check is a part of life of every person, checking then financial health of the entity is part of its life cycles. Also in this book, the financial analysis is seen as a process of using financial information to support management decisions. Karen Berman and Joe Knight, highlights in the book The Financial Intelligence - The Manager Guide to Understanding the True Meaning of the Figures (2011), that the performance art is a product of entities finances determined based on the profit and loss account. Petersen Christian and Plenborg Thomas approach the subject of the position and financial performance in the book Financial Statement Analysis: valuation, credit analysis, executive compensation (2012). Also, Young Jacob Davis and Cohen argue in the paper Corporate Financial Reporting and Analysis (2013) that the main purpose of the analysis of financial position and performance is to assess the quality of financial statements and adjust them where necessary. Romanian literature provides a theoretical approach on the financial position and performance, strengthening existing international ideas and approaches in their own way the main features existing on this subject. The author Petrescu Silvia, in the book entitled Analysis and Diagnosis Accounting (2010) develops the provisions of IAS 1 - Presentation of Financial Statements, illustrating the importance of financial position of entities based on the analysis of economic resources controlled (assets) and financing 
structure (debt and equity). A look on the financial position and performance ensemble is found in the paper written by Nicolae Baltes - Financial Analysis and diagnosis (2010), who treated the main indicators of economic and financial analysis. Financial performance is treated in detail in the book: Economic and Financial Analysis of the Company (2014), written by Robu Vasile, Anghel Ion and Serban Elena. According to the authors performance recorded when an entity is effective and efficient at the same time. These are just some of the references that were the support of this paper. A detailed picture of the theoretical support of this paper is highlighted in the bibliography section illustrated at the end of this paper.

\section{Research methodology}

The sample chosen for research consists of the top 30 drug companies operating in Romania, which account for over $90 \%$ of the market. The performance of the pharmaceutical industry in Romania has risen as a result of the evolution of the financial return indicator, a fact that was determined by using the Du Pont analysis as a model for measuring the financial performance of business entities (Baltes, N., Mihut, D., 2015, pp. 44-48), from 2009 to 2014.

One of the most widely used and useful models of breaking down indicators (Soliman, M., 2008), the Du Pont analysis measures the performance of economic entities, emphasizing the relationship between the economic rate of return and the financial rate of return. The model offers future orientations to financial management in order to eliminate the factors that lead to the poor performance of the activities of economic entities. The breakdown of the financial rate of return is outlined from the perspective of Du Pont model in Fig. 1.

It may be noted that the trend of financial return is influenced by a number of factors, which, when approached and interpreted in a holistic manner, can lead to better management of resources and to outlining appropriate financial strategies.

In order to determine the variables that influence the trend of financial return, we have used multiple linear regressions (Mukherjee, C.; White, H.; Wuyts, M., 1998), a model that involves explaining the relationship of dependency between variables that are set within the function specified below. The overall model of the regression function (Hill, C.; Griffiths, W.; Lim, G., 2008, p.110) is the following:

$$
\mathrm{Y}=\boldsymbol{\beta}^{\prime} \mathbf{0}+\boldsymbol{\beta}^{\prime} \mathbf{X 1}^{+}+\boldsymbol{\beta}^{\prime} \mathrm{X}^{2}+\ldots+\boldsymbol{\beta}^{\prime} \mathrm{Xn}+\varepsilon
$$

Where: $\mathrm{Y}$ - dependent variable;

$\mathrm{X} 1, \mathrm{X} 2 \ldots \mathrm{Xn}$ - independent variables;

$\boldsymbol{\varepsilon}-$ residual variable.

DE GRUYTER

OPEN 


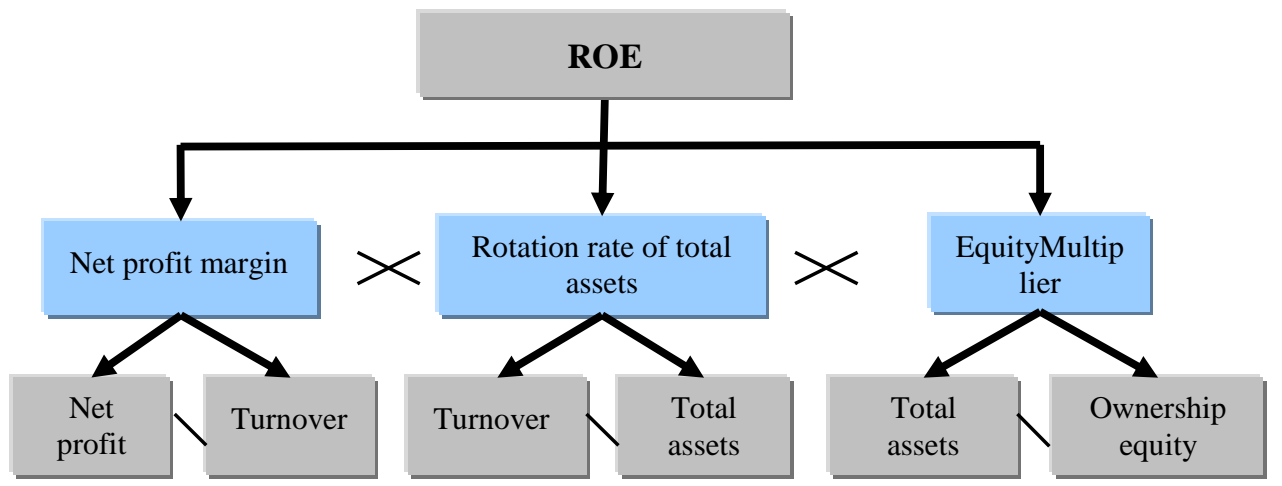

Figure 1: Breakdown of the rate of financial return according to Du Pont Model Source: adapted from Berk, Jonathan; De Marzo, Peter (2014), Corporate finance, Third Edition, Pearson Education, USA, pp. 44.

\section{Research on the Performance of the Pharmaceutical Industry in Romania} Depending on the main development of the rate of financial return, the share of entities operating in the pharmaceutical industry in Romania within the whole industry from 2009 to 2014 is shown in Chart 2.

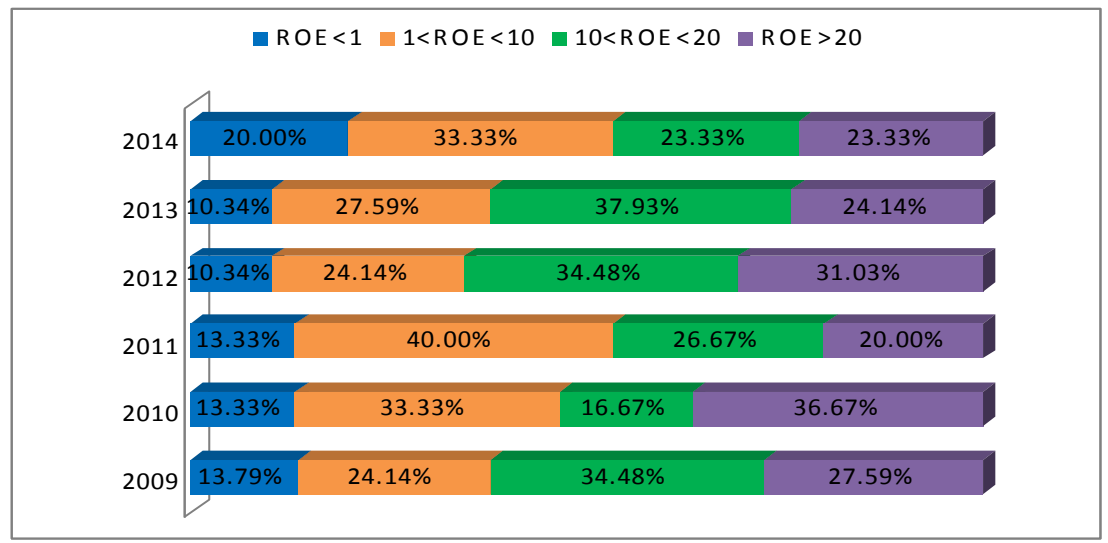

Chart 2: The evolution of the share of pharmaceutical companies within the whole industry from the perspective of financial return from 2009 to 2014

Source: Data processed by the authors on the basis of annual financial statements from 2009 to 2014, available on the website www.bvb.ro and on www.mfinante.ro 
Raising the rate of financial return for companies in the pharmaceutical industry involves an increase in the share of entities recording a value of the indicator below par, from $13.79 \%$ in 2009 to $20 \%$ in 2014 , which indicates a reduced capacity of these entities to make a profit by means of ownership equity. The share of entities registering a value of the indicator between $10 \%$ and $20 \%$ decreased in the period under review by over $11 \%$, while the share of those with a value of over $20 \%$ fell from 2009 to 2014 with $4.26 \%$. By analysing the evolution of the share of companies in the pharmaceutical industry based on the trend of the financial rate of return, we can estimate that the number of entities that resort to supporting the financial activities from loans and liabilities is growing in the period under analysis. This is due mainly to the liquidity crisis faced by entities, as a result of the high recovery duration of debts (average debt collection for the period under discussion exceeds 200 days).

Much more favourable is the financial situation of entities operating in the pharmaceutical industry, listed on the Bucharest Stock Exchange (Chart 3).

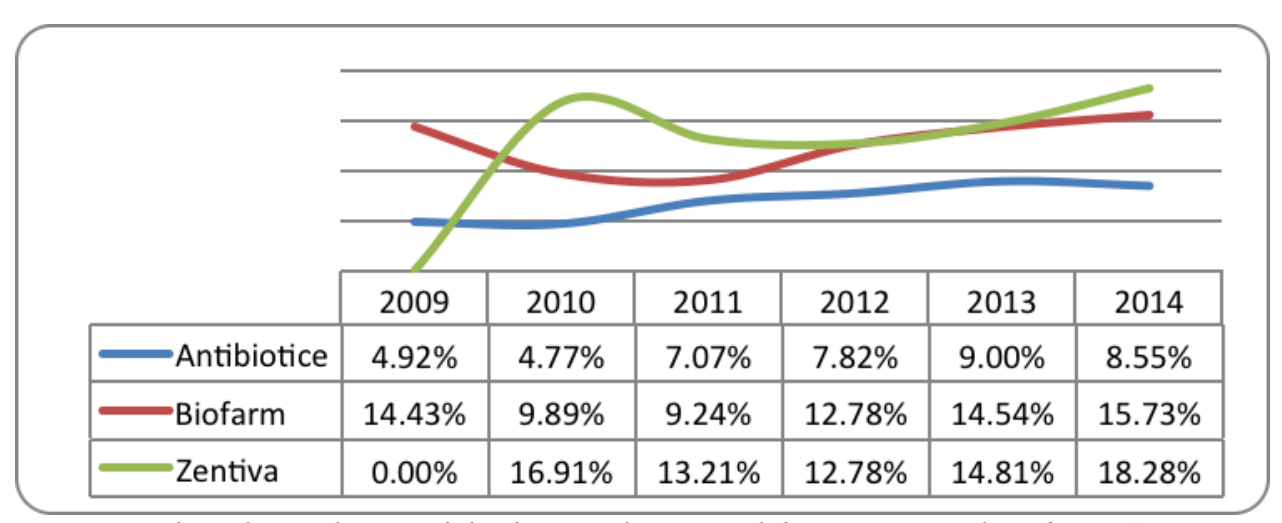

Chart 3: Evolution of the financial return of the companies listed on BSE from 2009 to 2014

Source: Data processed by the authors on the basis of annual financial statements from 2009 to 2014, available on the website www.bvb.ro

Unlike unlisted companies, those that are listed appear to have made a profit by means of ownership equity during the period under investigation (the only listed company which recorded a negative value of the indicator and only for one year is Zentiva).The identification of the factors that influence the financial rate of return from the pharmaceutical industry for the period 2009-2014 was based on the multiple regression model. We calculated the average values of the variables within the whole industry, the data being then processed with the help of mathematical and statistical analysis software IBM SPSS Statistics V 20. The model was 
Baltes N., Minculete (Piko) G.D., (2016)

Study on the financial performance of companies operating in the pharmaceutical industry in Romania

implemented by the step-by-step insertion of the independent variables, and the initial results of the regression model are shown in Table 1.

Table 1: Regression models determined by the coefficient of multiple determinations

\begin{tabular}{|c|c|c|c|c|}
\hline Regression model & $\begin{array}{l}\text { R(Multiple } \\
\text { correlation } \\
\text { coefficient) }\end{array}$ & $\begin{array}{c}\text { R Square } \\
\text { (Coefficient of } \\
\text { multiple } \\
\text { determination) }\end{array}$ & $\begin{array}{l}\text { Adjusted } \\
\text { R Square }\end{array}$ & $\begin{array}{c}\text { R Square } \\
\text { Change }\end{array}$ \\
\hline $\mathrm{ROE}=\beta^{\prime} 0+\beta^{\prime} \mathrm{MPN}+\varepsilon$ & 0.743 & 0.553 & 0.441 & 0.553 \\
\hline $\mathrm{ROE}=\beta^{\prime} 0+\beta^{\prime} \mathrm{MPN}+\beta^{\prime} \mathrm{ROA}+\varepsilon$ & 0.745 & 0.555 & 0.259 & 0.003 \\
\hline $\begin{array}{l}\mathrm{ROE}=\beta^{\prime} 0+\beta^{\prime} \mathrm{MPN}+\beta^{\prime} \mathrm{ROA}+\beta \\
{ }^{\prime} \mathrm{MCP}+\varepsilon\end{array}$ & 0.928 & 0.861 & 0.653 & 0.306 \\
\hline $\begin{array}{l}\mathrm{ROE}=\beta^{\prime} 0+\beta \text { 'MPN }+\beta^{\prime} \mathrm{ROA}+\beta \\
\text { 'MCP+ } \beta \text { 'INF }+\varepsilon\end{array}$ & 0.993 & 0.986 & 0.929 & 0.125 \\
\hline
\end{tabular}

Source: The authors 'calculations performed in SPSS on the basis of the dates available on: www.bvb.ro,www.mfinante.ro,www.insse.ro,www.europa.eu.

Where: $\mathrm{ROE}$ - return on equity

MPN - net profit margin

ROA - economic profitability

MCP - equity multiplier

INF - inflation

A more thorough analysis of the regression model presented above will be based on model 4 in the table above:

ROE $=\beta^{\prime}$ O $+\beta^{\prime}$ MPN $+\beta^{\prime}$ ROA + $\boldsymbol{\beta}^{\prime}$ MCP + $\boldsymbol{\beta}^{\prime}$ INF + $+\varepsilon$

Detailed information on this regression model is shown in Table 2.

Table 2: Details of model 4 of multiple linear regressions

\begin{tabular}{|c|c|c|c|c|c|c|}
\hline $\mathrm{R}$ & R Square & $\begin{array}{c}\text { Adjusted } \\
\text { R Square }\end{array}$ & $\begin{array}{c}\text { The standard } \\
\text { error of } \\
\text { estimated } \\
\text { variable }\end{array}$ & $\begin{array}{c}\text { R Square } \\
\text { Change }\end{array}$ & F Change & $\begin{array}{c}\text { Durbin- } \\
\text { Watson }\end{array}$ \\
\hline 0.993 & 0.986 & 0.929 & 1.691 & 0.125 & 8.815 & 2.790 \\
\hline
\end{tabular}

Source: the authors' calculations performed in SPSS

Thus, the first column R contains the multiple correlation coefficients, showing the meaning of the link between the values observed and the predicted values. The value of 0.993 shows the positive side of the relationship between the observed and 
the predicted values of financial return, offering a first indication of the consistency of the regression model. The value of 0.986 of the coefficient of multiple determination measures the intensity of the link, expressed by the regression equation. Thus, $98.6 \%$ of the variation of financial return is determined by the variation of the variables involved, i.e. the net profit margin, return on assets, equity multiplier and inflation. The remaining variation of $1.4 \%$ is due to the variation of residual variable $\varepsilon$.

The step-by-step design of the regression model increases the value of the coefficient of multiple determinations with each independent variable added. There may be situations when the impact of certain independent variables may be minimal or nonexistent. To avoid such situations, we calculated the adjusted multiple coefficient of determination (Tichindelean M., 2014 p. 130). The adjusted coefficient of multiple determinations is close to R Square, confirming the effect of the last variable introduced - inflation - on the variation in the dependent variable. The standard error of the estimated variable refers to the average deviation of the residual variable from its average value, in this case the deviation being 1.691.

A change in the R Square indicator expresses the extent to which the variation of the dependent variable determines the variation of the last variable included in the regression model. $\mathrm{R}$ Square increases by $12.5 \%$ due to the inclusion in the regression model of the last variable, i.e. inflation.

Moreover, the statistical significance of the regression model entails testing the null hypothesis that the coefficient of multiple determination is 0 (Tichindelean M., 2014 p. 130). The value of 8.815 corresponding to column $F$ Change indicates the change in the calculated value of $\mathrm{F}$ by the additional variation of $\mathrm{R}$ Square, as a result of including the last variable under discussion. The indicated value of 8.815 is statistically significant, with a tiny probability that it could be due to chance, to the detriment of a genuine relationship.

The Durbin-Watson statistic offers clues with regard to the hypothesis of the lack of autocorrelation of the residual variable. It is also recommended that a review of the regression model should be made if the value of the Durbin-Watson statistic is less than 1or if it exceeds 3 (Tichindelean, M., 2014 p. 131). In this case, the value of the indicator is 2.790 , the regression model being valid in terms of the lack of autocorrelation of the residual variable. The values of the estimated parameters of the equation are presented in Table 3.

The parameters of the regression model were estimated by using the method of least squares on the basis of the values of $\beta$ '. The following form of the regression equation was obtained:

ROE $^{\prime}=-22.593-4.122 \mathrm{MPN}+7.402 \mathrm{ROA}+7.603 \mathrm{MCP}+1.503 \mathrm{INF}$

DE GRUYTER OPEN 
Baltes N., Minculete (Piko) G.D., (2016)

Study on the financial performance of companies operating in the pharmaceutical industry in Romania

Table 3: Table showing data specific to the predicted parameters of the regression model

Coefficients $^{\mathrm{a}}$

\begin{tabular}{|c|c|c|c|c|c|c|c|c|}
\hline & \multirow{2}{*}{ Model } & \multicolumn{2}{|c|}{$\begin{array}{l}\text { Non-standardised } \\
\text { Coefficients }\end{array}$} & \multirow{2}{*}{$\begin{array}{c}\text { Standardised } \\
\text { Coefficients } \\
\text { Beta }\end{array}$} & \multirow{2}{*}{$\mathrm{t}$} & \multirow{2}{*}{ Sig. } & \multicolumn{2}{|c|}{$\begin{array}{l}95.0 \% \text { Confidence } \\
\text { Interval for B }\end{array}$} \\
\hline & & B & $\begin{array}{l}\text { Std. } \\
\text { Error }\end{array}$ & & & & $\begin{array}{l}\text { Lower } \\
\text { Bound }\end{array}$ & $\begin{array}{l}\text { Upper } \\
\text { Bound }\end{array}$ \\
\hline \multirow{3}{*}{1} & (Constant) & -5.104 & 11.146 & \multirow{3}{*}{.743} & -.458 & .671 & -36.051 & 25.842 \\
\hline & MPN & 2.237 & 1.006 & & 2.223 & .090 & -.557 & 5.031 \\
\hline & (Constant) & -4.875 & 12.953 & & -.376 & .732 & -46.098 & 36.348 \\
\hline \multirow[t]{3}{*}{2} & MPN & 1.819 & 3.405 & .604 & .534 & .630 & -9.017 & 12.655 \\
\hline & ROA & .544 & 4.166 & .148 & .131 & .904 & -12.714 & 13.802 \\
\hline & (Constant) & -21.330 & 11.820 & & -1.805 & .213 & -72.188 & 29.527 \\
\hline \multirow{5}{*}{3} & MPN & -1.533 & 2.822 & -.509 & -.543 & .641 & -13.674 & 10.608 \\
\hline & ROA & 4.878 & 3.516 & 1.325 & 1.387 & .300 & -10.251 & 20.008 \\
\hline & MCP & 6.562 & 3.122 & .683 & 2.102 & .170 & -6.870 & 19.994 \\
\hline & (Constant) & -22.593 & 5.353 & & -4.221 & .148 & -90.603 & 45.417 \\
\hline & MPN & -4.122 & 1.544 & -1.370 & -2.670 & .228 & -23.735 & 15.492 \\
\hline \multirow[t]{3}{*}{4} & ROA & 7.402 & 1.800 & 2.010 & 4.111 & .152 & -15.475 & 30.278 \\
\hline & MCP & 7.603 & 1.452 & .792 & 5.235 & .120 & -10.849 & 26.054 \\
\hline & INFLATION & 1.503 & .506 & .455 & 2.969 & .207 & -4.931 & 7.937 \\
\hline
\end{tabular}

a. Dependent Variable: ROE

Source: The authors' calculations performed in SPSS

The sign of the estimated parameters indicates how the variables in question influence the effect variable. Thus, the financial return of pharmaceutical companies is positively influenced by their economic profitability, by the equity multiplier and by inflation, and negatively, by the net profit margin. As we know the inflation is a phenomenon which has a negative impact on economy on medium and long term (Mera, V.; Silaghi, Pop, M., 2015). In our case study, inflation has had a positive impact on the financial return of pharmaceutical companies, because even if the prices of the drugs go up, the demand will be the same. It follows that the higher the economic profitability and equity multiplier, the higher the financial return in the pharmaceutical industry, and that the lower the value of the net profit margin, the lower the financial return.

\section{Conclusions}

By using the multiple linear regression models, we can notice the factors that have an influence on the change in the rate of financial return. We found that an increase in the variables of economic profitability, equity multiplier and inflation has a positive influence on the rate of financial return. The variable with a negative influence on financial return is the net profit margin. When this independent 
variable goes down, it will have a negative impact on financial return, leading to its decrease.

\section{Bibliography}

1. Baltes, Nicolae (2010), Analiza si diagnostic financiar, Editura Universitatii „Lucian Blaga” din Sibiu;

2. Baltes, Nicolae (coord.); Mihut, Diana (2015), Analiza performantei financiare la societatile listate si tranzactionate la Bursa de Valori Bucuresti, Sibiu- Teza de doctorat.

3. Berk, Jonathan; DeMarzo, Peter (2014), Corporate finance,ThirdEdition, PearsonEducation, USA;

4. Berman, Karen; Knight, Joe (2011), Inteligenta financiara: Ghidul managerului pentru intelegerea adevaratei semnificatii a cifrelor, Editura Curtea Veche, Bucuresti;

5. Bodie, Zvi; Merton, Robert (2000), Finance,Prentice-Hall Inc., New Jeresy;

6. Burghelea, Cristina; Gheorghiu, Anda; Tindechea, Cristina; Gheorghiu, Anca (2014), Global European economic model, Theoretical and Applied Economics, Volume XXI (2014), No. 3(592): www.ectap.ro.

7. Cotter, Derry (2012), Advanced Financial Reporting - a Complete Guide to IFRS, Pearson Education Limited;

8. Eakins, Stanley, Finance - Investments, Institutions and Management (1999), Addison-Wesley Educational Publishers Inc., United States of America;

9. Higgins, Robert (2012) Analysis for Financial Management, TenthEdition, United States;

10. Hill, Carter; Griffiths, William; Lim, Guay (2008), Principles of Econometricsm, Third Edition, John Wiley\&Sons, Inc., USA;

11. Kotler, Philip; Caslione, John (2009), Chaotics: management and marketing in the age of turbulence, Publica Publishing, Bucuresti;

12. Mera, Valentina; Silaghi-Pop, Monica, An Insight Regarding Economic Growth and Monetary Policy in Romania, Scientific Annals of the "Alexandru Ioan Cuza" University of Iasi Economic Sciences 62 (SI), 2015, 85-95, DOI 10.1515/aicue-2015-0039;

13. Minculete (Piko), Georgiana; Baltes, Nicolae, Economic and Financial Implications of the Pharmaceutical Industry in Romania, Revista Studia Universitatis "Vasile Goldis", Numarul 1, Volumul 24, 2014;

14. Mocnik, Dijana; Sirec, Karin, Determinats of a Fast-Growing firm's profits: Empirical evidence for Slovenia, Scientific Annals of the "Alexandru Ioan Cuza" University of Iasi Economic Sciences 62 (1), 2015, 37-54, DOI 10.1515/aicue-2015-0003; 
15. Mukherjee, Chandan; White, Howard; Wuyts, Marc (1998), Econometrics and data analysis for developing countries, Routledge, UK;

16. Petersen, Christian; Plenborg, Thomas, Financial StatementAnalysis: valuation, credit analysis, executive compensation, Prentice Hall Financial Times Edition, 2012, England, ISBN: 978-0-273-75235-6;

17. Petrescu, Silvia (2010) Analizasi diagnostic financiar-contabil, Editia a III-a revizuitasi actualtizata, Editura CECCAR, Bucuresti;

18. Robu, Vasile; Anghel, Ion; Serban, Elena-Claudia (2014) Analiza economicofinanciaraa firmei, Editura Economica, Bucuresti;

19. Soliman, Mark (2008), The Use of DuPont Analysis by Market Participants, The Accounting Review, Vol. 83, No. 3: http://faculty.haas.berkeley.edu /kli/papers/Soliman-2008TAR.pdf.

20. Tichindelean, Mihai (2014), Marketing relational - abordare teoreticasi instrumentala, Editura Pro Universitaria, Bucuresti;

21. Young, David; Cohen, Jacob (2013), Corporate Financial Reporting and Analysis - a Global Perspectiv, John Wiley \& Sons Ltd, England;

22. The pharmaceuticalindustry in Romania: maintrendsandthe impact on societyandtheeconomy (2011), Institute for Economic Forecasting, 2011:

23. http://www.lawg.ro/files/assets/userfiles/files/Industria\%20Farmaceutica\%20di n\%20Romania.pdf

24. http://www.firme.info/fabricarea-produselor-farmaceutice-baza-preparatelorfarmaceutice-COD-CAEN-21/p14.html;

25. http://iri.jrc.ec.europa.eu/scoreboard14.html.

26. www.bvb.ro;

27. www.mfinante.ro;

28. www.insse.ro;

29. www.europa.eu. 